\title{
ケイ光性界面活性剤の性質と応用
}

\author{
近藤保 \\ 東京理科大学薬学部 (新宿区市ケ谷船河原町)
}

\section{Fluorescent Surface-active Agents, Their Properties and Possible Applications \\ Tamotsu Kondō}

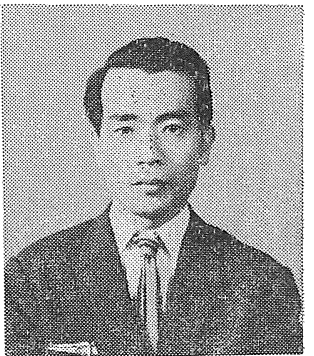

Faculty of Pharmaceutical Sciences, Science University of Tokyo (Ichigaya, Shinjuku-ku, Tokyo)

\section{序}

論

界面活性剤の界面および溶液中の挙動に関してはすで に数多くの研究がなされ，、ろいろ興味ある知見が得ら れて実用上の貴重な指針を提供している。しかしなおこ れらの挙動は完全に理解されたとはいえず，たとえば 水一油界面に打江吸着や $\mathrm{cmc}$ 以下の低濃度水溶液中の 挙動などの未解決の問題を残している。

界面における界面活性剤の挙動については，とくに 水一空気界面においての研究が非常に多く, 界面におい ての分子の吸着量の直接測定さ光行なわれている ${ }^{1)}$ 。こ の上うな研究は放射性同位体を含む界面活性㓮の利用に 負らところが多い。

他方, 水一油界面におけるこれらの物質の挙動につい ての研究は水-空気界面の場合よりも少ない。乳化のよ らな実用面において必要なのは水一油界面における知見 で，これは水-空気界面のものとは相当異なっているに 違いない。乙かし現在では水一油界面に拉ける研究が少 ないので, 水-空気界面での知見から類推を行なってい る状態である。研究の少ない理由の一つは水一油界面で 放射線が油により吸収されるため放射性界面活性剂の威 カが発揮できないことであるう。

$\mathrm{cmc}$ 以下の濃度の界面活性剂水溶液中で，な九らか の形の（たとえば 2 分子会合のような形の）分子会合が 起きていることは，とくにイオン性界面活性剤について 電気伝導度測定から，かなり確定的な裏書きがされてい

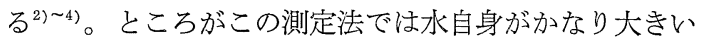
伝導度をもっているために低濃度における伝導度の正確 な值を求めることは困難である。

さて著者はかなり以前にケイ光色素と界面活性剂間の 相互作用を研究していたが5)，そのとき観察した外的条 件の変化に伴って起こるケイ光強度の増大や減少は非常 に印象的であった。したがってケイ光強度の測定が放射 能の場合に匹敵しうるほど鋭敏であることを考えると， 界面活性剤自身がケイ光を発すれば他の手段では解明が 不可能であった前述のような現象がケイ光強度測定によ
って解明できるようになりうるであろうという予想をい だくに至った。またさらにこのような物質はケイ光増白 剤やケイ光探傷剤としても利用できるであろらし，他の 応用も開けてくるであろう。そしてこれが動機となって 以下に述べるようないくつかの化合物が合成され，性質 が調べられた。しかし応用についてはまだ充分なデータ がないので主として可能性について記すにとどめる。

\section{1 合成の原理}

初めに順序として合成の原理を述べる。ケイ光性界面 活性剂はつぎの二つの方法によって合成が可能である。 すなわち

1）ケイ光色素あるいは中間体の分子中に長鎖アル キル基を導入する方法

2）界面活性剤分子中にケイ光性の原子団を導入す る方法 である。

はじめの方法で合成した化合物の例は 4, $4^{\prime}$-ジアシル アミノスチルベン-2,2'年ージスルン酸ナトリウム（以下 DAS と略称 $)^{6)}, 4,4^{\prime}$-ビスー(2-アルキルアミノ-4-スル ファニル-1,3,5-トリアジル-6)-アミノスチルベン-2,2' ージスルホン酸ナトリウム (以下 BATS と略称 ${ }^{7)}$ ，およ び 1-アシルアミノナフタレン-5-スルホン酸ナトリウム (以下 $\mathrm{AN}$ と略称 $)^{8)}$ がある。第二の方法で合成した化合 物の例はアルキルアミノプロピオン酸フェニルフェナシ ルエステル (以下 AP と略称) $)^{9}$ がある。

\section{2 水溶液の性質}

実際に合成された化合物が通常の界面活性剂と同様に 界面活性であり，かつまたケイ光性であることを示すた めに，水溶液の表面張力とケイ光スペクトルを測定した 結果を述べる。

\section{$2 \cdot 1$ 水溶液の表面張力}

界面活性剤の表面張力一濃度曲線はある濃度において 屈折点を示し，それ以上の濃度ではほぼ一定值の表面張 力を与える。屈折点に対応する濃度は $\mathrm{cmc}$ である。こ 


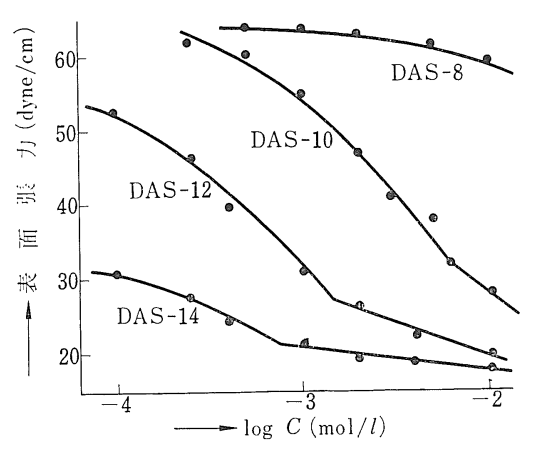

図-1 DAS 水溶液の表面張力 $\left(70^{\circ} \mathrm{C}\right)$

れとまったく同じ挙動をケイ光性界面活性剂が示すこと はつぎの 図-1 3 で明らかである。な挔表面張力はすべ て滴重法を用いて測定した。図中の化合物の略称のあと の数字は長鎖疎水基中の炭素原子数を意味する。DAS8 では表面張力曲線上に屈折点が現われていないが，も っと高浱度で電気伝導度測定を行なった際には屈折点が 認められている6)。いま図の屈折点を $\mathrm{cmc}$ とすると, DAS についてそれらの值は DAS-14 では $0.8 \times 10^{-3}$ $\mathrm{mol} / l$, DAS-12 で $1.7 \times 10^{-3} \mathrm{~mol} / l$, DAS-10 で $5.2 \times$ $10^{-3} \mathrm{~mol} / l$, DAS-8 で $12.2 \times 10^{-3} \mathrm{~mol} / l$ となる。した がって cmc の值は踈水基の炭素原子数によってほぼ等 比級数的に変化することがわかる。 $\mathrm{cmc}$ の対数と疎水基 の長さとの関係は実験式 $\log \mathrm{cmc}=-0.214 N-0.17$ と なる。ここで $N$ は疎水基中の炭素原子数である。この ような関係は通常の界面活性剤についてはよく知られて いるものである。

DAS 変形した BATS の水溶液の表面張力曲線も 同じような挙動を示ず)。ただ分子量が大きいためDAS より水に封する溶解度が小さい。

図-2 は AN 水溶液の表面張力曲線で，いずれも界面 活性剤に特有な挙動が現われている8)。ただこの場合に は疎水基の炭素原子数が多いほど表面張力低下能力は小 さくなっている。これは怙そらくナフタリン核が蹯水基 の役目をするので疎水基中の有效炭素原子数が約 4 個分 だけ増大するためと考えられる。一般の界面活性剤の場

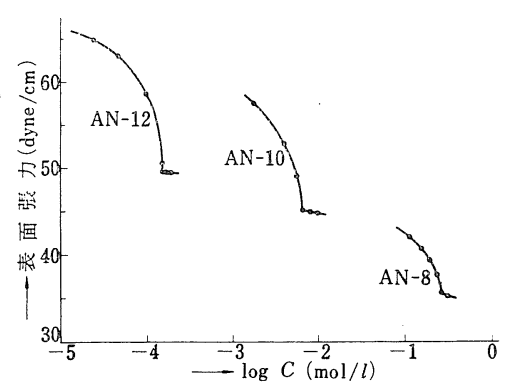

図-2 $\mathrm{AN}$ 水溶液の表面張力 $\left(50^{\circ} \mathrm{C}\right)$

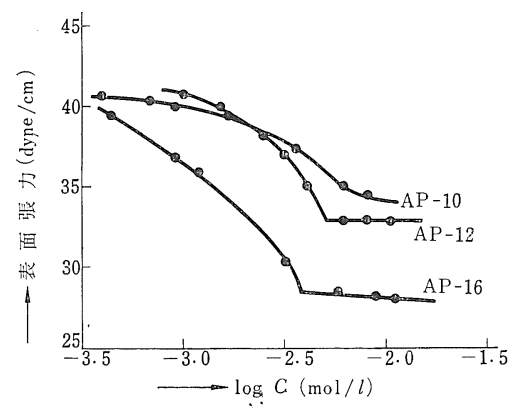

図-3 AP 水溶液の表面張力 $\left(60^{\circ} \mathrm{C}\right)$

合にも表面張力低下能が最大になるのは疎水基中の炭素 原子数が 12 個付近で, それ以上疎水基が長くなると cmc は小さくなるが表面張力低下能が減少する。

表面張力曲線の屈折点を $\mathrm{cmc}$ とすると, $\mathrm{AN}-12$ で $1.5 \times 10^{-4} \mathrm{~mol} / l, \mathrm{AN}-10$ で $6.6 \times 10^{-3} \mathrm{~mol} / l, \mathrm{AN}-8$ で $2.7 \times 10^{-1} \mathrm{~mol} / /$ となる。この場合にも $\mathrm{cmc}$ の対数と疎 水基中の炭素原子数 $N$ の間には直線関係がある。すな わち $\log \mathrm{cmc}=-0.80 N+5.87$ の実験式が成立する。

図-3 に示したのは AP 水溶液の表面張力曲線である。 これらの化合物は純水には不溶性なので酢酸々性の水溶 液として表面張力を測定してある9

AP-10 は測定した濃度範囲では屈折点を示さなかっ たが，AP-12 および AP-16 では明りょうな屈折点が 観測された。この点に対応する濃度を $\mathrm{cmc}$ とするとそ の値は AP-16 で $3.6 \times 10^{-3} \mathrm{~mol} / \mathrm{l}, \mathrm{AP}-12$ で $4.7 \times 10^{-3}$ $\mathrm{mol} / l$ となる。

\section{$2 \cdot 2$ ケイ光スペクトル}

水溶液のケイ光スペクトルの極大強度を示す波長はざ の系列の化合物に対しても疎水基中の炭素原子数には無 関係であった。ケイ光スペクトルを得るに用いた励起光 の波長はそれぞれの化合物の紫外部吸収スペクトルの極 大吸收波長に近い。

図-4 6 にいくつかの化合物のケイ光 スペクトルを示 した。

DAS にトリアジン環を導入した BATS のケイ光ス

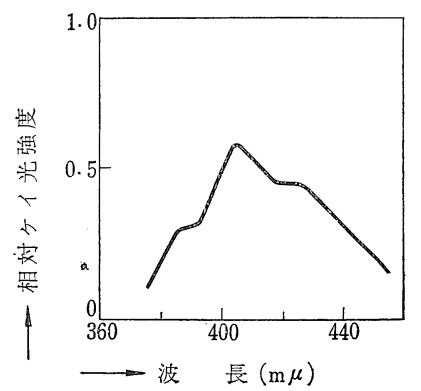

図-4 DAS-10 メタノール溶液のケイ光スペクトル6) (DAS-10 濃度 : $1.7 \times 10^{-} 4 \mathrm{~mol} / l$ ) 


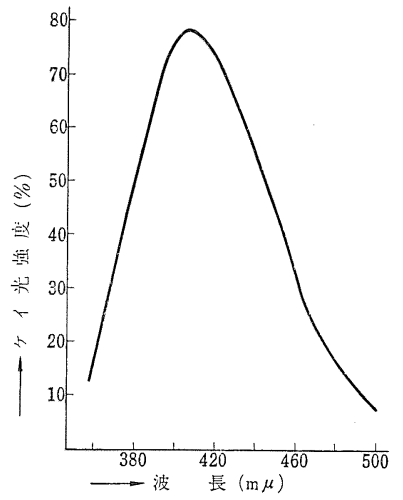

図-5 AN-10 水溶液のケイ光スペクトル ${ }^{8)}$ (AN-10 濃度 :

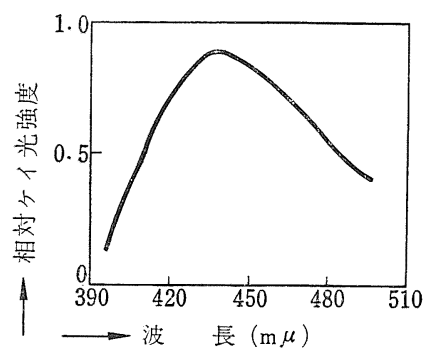

图-6 BATS-6 水溶液のケイ光スペクトル7) (BATS-6 濃度 : $1.0 \times 10^{-4} \mathrm{~mol} / l$ )

ペクトルは長波長側に移動し，ケイ光強度の極大は 440 $\mathrm{m} \mu$ 付近に見られる。このことはケイ光増白剤への応用 を考える場合に重要である。なお 図-6 には BATS-6 のケイ光スペクトルが示してあるが，これはもっと長い 疎水基を持つ化合物の水に対する溶解度が小さいためで ある。

AP のエタノール中におけるケイ光スペクトルの極大 を示す波長は $470 \mathrm{~m} \mu$ である

\section{3 可能な応用例}

前節においてケイ光性界面活性剤溶液の性質を述べた ので，今度はこれらの化合物の可能な応用面について荐 えてみよう。

\section{3・1 基礎研究における応用}

界面に配向吸着された分子がケイ光を発すれば，その ケイ光強度を測定することにより吸着量を求めることが できる。水-油界面における吸着量の直接測定はこのよ うにして可能となるであろら。ただ測定されたケイ光強 度は一般に界面に吸着した分子よりのものと水中に溶解 した分子からのもの念含むから，界面に吸着されない界 面不活性同族列化合物の同濃度溶液についてあらかじ 同一条件でケイ光強度測定を行なっておいて，その值を 界面活性化合物の測定值からさし引いて補正をする必要
がある。この種の実験については目下著者の研究室で検 討しつつある。ケイ光性界面活性剤の中には DASのよ うに光照射によってシスせトランス異性化を起こし，乙 かもケイ光性なのはトランス形のみであるような化合物 があるが，このような化合物は上記の目的には不適当で ある。

溶液中において界面活性剤分子が $\mathrm{cmc}$ よりもかなり 低濃度で会合している証拠があることはすでに㙄摘し た。この現象をケイ光強度測定によって追跡することが 可能である。一般に水溶性ケイ光物質は濃度を増すとケ イ光強度が低下するが，これは水中で分子会合が起きる ためと考えられている。これとまったく同じような現象 が $\mathrm{AN}$ 水溶液についても見られる いて AN 濃度が非常に小さいときにはケイ光強度が濃 度に比例して増加し Lambert-Beer 型の法則に従うが， 濃度が増すにつれてこの直線法則から偏いする。この偏 いが起きる濃度は $\mathrm{cmc}$ よりも小さく, 溶液中でなんら かの変化が生じたことを示唆している。この濃度に対す る塩の效果から考えて, 直線法則からのずれは分子会合 によるためらしい。実際に会合が起きていることを確か めるには他の手段を併用する必要があると思われる。

最近ケイ光染料の非常に低濃度における会合現象が高 分解能 NMR によって行なわれている ${ }^{11)}$ 。濃度が通常 の NMR 測定よりも低いので穦算計を用いて多数回の scanning を行なった結果, 明らかな会合を認めた。こ れと同じ方法を用いて AN の NMR 測定を目下行ない つつある。ただ AN は染料に近い構造をもっているの でそれだけでも会合性を示すことが予想され，したがっ てもし実際に会合が確認されても，その原因は染料とし ての会合性と界面活性剤としての会合性が重なり合った ためと考えられる。そこで AN の基本骨格である Laurent 酸ナトリウムの会合性を検討しておく要がある。

図-7 (a) と（b）はそれぞれ AN と通常の脂肪酸セ ッケンの水溶液から作った気ホウを紫外線ランプの照明 下に撮影した写真である。(a) と（b) の著しい差は前者

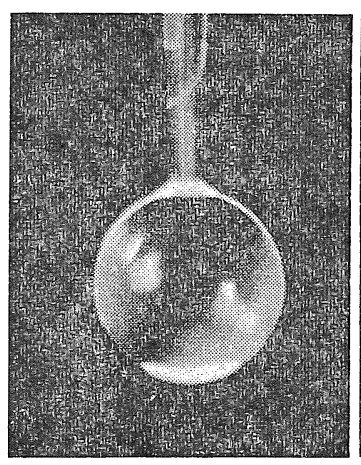

（a）AN 水溶液から作った 気ホウ

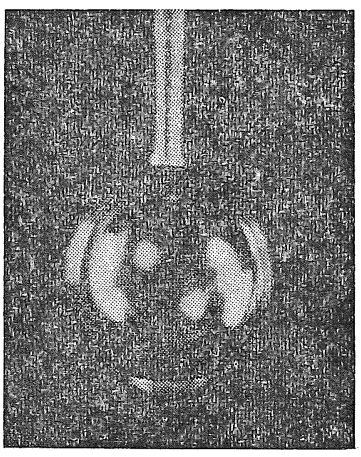

（b） ラウリン酸ナトリウム水 溶液から作った気ホウ
図-7 
では AN の発するケイ光のためにアワの輪郭が明りょ らであるが，後者ではランプの光の反射光のみなので 輪郭は不明りょうである。ケイ光性界面活性剂水溶液加 ら作った気ホウは排液が進行して膜が薄くなり，遂に破 裂するまでケイ光が観察できる。すなわち通常の界面活 性威水溶液のアワの場合に見られる，排液が進行した後 での黒膜は存在しないように思われる。もっともこれは 紫外線下に拉いての話であるが，それにしてもケイ光性 界面活性剂を用いてホウ膜の研究を行なえばなにか新し 、知見が得られるように思われる。

その他の可能な応用面として注生物学や医学分野にお ける大きい吸着能力と強いケイ光を利用したトレーサー 的な利用が考光られる。

\section{2 実用面における応用}

ケイ光性物質をいるいる実用的に利用することは古く 加ら行なわれている。これらの物質に強い界面活性を与 えれば吸着能力が著しく増大するので，それが長所と なるようなときには大きい威力を発揮するものと思われ る。

わが国では十数年前から合成洗剤中にケイ光染料を添 加し，白色布上に吸着された染料の発する青味を帯びた ケイ光によって布をより白く見せることが広く行なわれ ている。この場合添加されるケイ光染料はスチルベン系 のものがおもなようで添加量もかなり多い。そのため望 ましくない点もいくつか見られる。すなわちコスト高と なり，また白色布上に吸着した染料が変質して布を污染 することもあるようである。

このよらな欠点を除き少量で効果を現わす可能性が DAS によって与光られる。表-1 は無ケイ光のモメン布 に種々の条件下で DAS を染着させ，その布のケイ光強 度を判定した結果の一部である゙

表-1 染色布のケイ光強度

\begin{tabular}{c|c|c|c|c|c}
\hline 染着温度 $\left({ }^{\circ} \mathrm{C}\right)$ & DAS-2 & DAS-8 & DAS-10 & DAS-12 & DAS-14 \\
\hline 40 & \pm & \pm & + & + & + \\
60 & \pm & \pm & + & ++ & ++ \\
95 & \pm & \pm & + & ++ & ++ \\
\hline
\end{tabular}

土:わずかにケイ光が認められる，：ケイ光が明りょう に認めら秃る, +十：それ以上にケイ光加強い

上記の結果は染色濃度 $1 \%$ owf, ボウ硝 $10 \%$ owf, 浴 比 $1: 50$ でそれぞれの温度において $3 \mathrm{hr}$ 染色を行ない, 布のケイ光の強さを紫外線照射下で肉眼的に判定したも のである。DAS-2，DAS-8 で処理した布はほとんどケ イ光を示していないが，これらの化合物のモメンに対す る親和性が小さく，また水溶性が大きいためと考光られ る。DAS-10 以上の化合物では明らかにモメン布に対す る染着が大きいためにケイ光強度が大きくなっている。

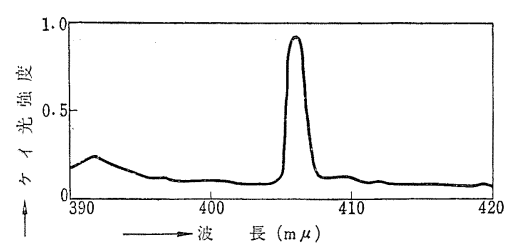

図-8 モメン布上の DAS-12 のケイ光スペクトル

図-8には DAS-12 で染着したモメン布のケイ光スペク トルを示す。

ケイ光強度の極大波長はメタノール溶液中と同じく $406 \mathrm{~m} \mu$ である。しかし増白効果はほとんどない。一般 に繊維のケイ光增白作用には 430 500 m $\mu$ のケイ光を 発する化合物が効果的であるといわれている ${ }^{12)}$ ので，こ のような結果もやむをえないかも知れない。しかし図-6 に示したように BATS のケイ光スペクトルは $440 \mathrm{~m} \mu$ 付近に極大定持つのでかなりの増白効果分期待できる。 これについては目下染着試験を計画している。

物体に傷があるかどうかを検査することは探傷といわ れており，鋳鉄，鋼鉄，各種合金，ガラス，プラスチッ クなどのいろいろの材料や，これらの材料から作られた 各種の製品の傷を調べることは大切な問題である。この 傷の検査が非破壞的に行なえればつごうがよい。非破壊 検查法の一つにケイ光をトレーサーに用いた方法があ り，ケイ光探傷法といわれている。この方法は傷の部分 にケイ光物質の吸着膜をつくり, これを紫外線下で観察 して傷を探し出す。吸着能力の大きいケイ光性界面活性 剤はケイ光探傷剤としても適当と考兄らる。

終わりにケイ光性界面活性剂の研究に当たり種タ御援助をい ただいたライオン油脂株式会社研究所に感謝する。 (昭和 42 年 12 月 6 日受理)

文献

1) 村松, 佐々木ら, コロイド化学討論会講演, 札幌 (1967)

2) K. Meguro, T. Kondo et al., Bull. Chem. Soc. Japan, 30, 760 (1957)

3) P. Mukerjee, K.J. Mysels, C.I. Dulin, J. Phys. Chem., 62, 1390 (1958)

4) J.S. Clunie, J.F. Goodman, P.C. Symons, Trans. Faraday Soc., 63, 754 (1967)

5) 近藤, 油化学, 8, 181 (1959)

6) 近藤, 岡川, 永山, 工化, 68, 2125 (1965)

7) 武者, 岡川, 近藤, 永山, 日化投稿予定

8) Y. Musha, A. Okagawa, T. Kondo, M. Nagayama, Bull. Chem. Soc. Japan, in press

9) 武藤, 近藤, 永山, 油化学, 15, 26 (1966)

10) 武者, 近藤, コロイド化学討論会講演, 札幌 (1967)

11) D.J. Blears, S.S. Danyluk, J. Am. Chem. Soc., 89, 21 (1967)

12）吉田, 高分子, 5, 274 (1956) 